\title{
SIMULATION OF SALT WASTE
}

\section{EVAPORATION/CRYSTALLIZATION (U)}

\author{
by E. G. Orebaugh
}

Westinghouse Savannah River Company

Savannah River Site

Aiken, South Carolina 29808

Other Authors:

This paper was prepared in connection with work done under Contract No. DE-AC09-89SR18035 with the U. S. Department of Energy. By acceptance of this paper, the publisher and/or recipient acknowledges the U. S. Government's right to retain a nonexclusive, royalty-free license in and to any copyright covering this paper, along with the right to reproduce and to authorize others to reproduce all or part of the copyrighted paper. 


\section{DISCLAIMER}

This report was prepared as an account of work sponsored by an agency of the United States Government. Neither the United States Government nor any agency thereof, nor any of their employees, makes any warranty, express or implied, or assumes any legal liability or responsibility for the accuracy, completeness, or usefulness of any information, apparatus, product, or process disclosed, or represents that its use would not infringe privately owned rights. Reference herein to any specific commercial product, process, or service by trade name, trademark, manufacturer, or otherwise does not necessarily constitute or imply its endorsement, recommendation, or favoring by the United States Government or any agency thereof. The views and opinions of authors expressed herein do not necessarily state or reflect those of the United States Government or any agency thereof.

This report has been reproduced directly from the best available copy.

Available to DOE and DOE contractors from the Office of Scientific and Technical Information, P.O. Box 62, Oak Ridge, TN 37831; prices available from (615) 576-8401, FTS 626-8401.

Available to the public from the National Technical Information Service, U.S. Department of Commerce, 5285 Port Royal Rd., Springfield, VA 22161. 


\begin{tabular}{ll} 
KEY WORDS: & \multicolumn{1}{c}{$\begin{array}{c}\text { sait waste } \\
\text { simulation } \\
\text { ProChem } \\
\text { Burkite }\end{array}$} \\
CC: & W.L. Tamosaitis 773-A \\
D. G. Karraker, 773-A \\
E. W. Baumann, 773-41A \\
D. L. Fish, 773-A \\
L. O. Dworjanyn, 779-2A \\
J. P. Bibler, 773-A \\
M. S Hay, 773-A \\
D. T. Hobbs, 773-A \\
D. J. McCabe, 676-T \\
J. R. Fowler, 704-Z \\
SRTC Records(4)
\end{tabular}

To: W.E. Stevens
From: E. G. Orebaugh eq

January 22,1993

\section{SIMULATION OF SALT WASTE EVAPORATION/CRYSTALLIZATION (U)}

\section{SUMMARY}

The database of ProChem software has been enhanced to account for the formation of the mineral, Burkite which can form in alkaline tank wastes during evaporation. This mineral was not suspected until recent evaporation/crystallization studies suggested its presence. The enhanced data base will predict its occurrence and realm of existence. If salt cake temperatures drop below $30^{\circ} \mathrm{C}$ the Burkite phase is unstable toward hydrated sodium carbonates and sulfates. ProChem will not predict if this phase is more or less rapidly dissolved than its component salts. The enhanced database improves our ability to simulate waste chemistry.

\section{BACKGROUND}

Recent concerns over quantification of uranium and plutonium in our waste-tanks resulted in some solubility tests by D. Karraker. Analysis of the solids and solutions resulting from evaporation/crystallization of simulated waste showed that most of the sulfate content was precipitated in salts. When the ProChem software leased from OLI Systems, Inc. was used to quantify and identify the species in the system, it predicted that the sulfate should still be completely soluble. The failure of the software and data base to emulate reality was communicated to OLI for evaluation. OLI determined the fault was the lack of database entries on ternary systems such as the $\mathrm{Na}_{2} \mathrm{CO}_{3}-\mathrm{Na}_{2} \mathrm{SO}_{4}-\mathrm{H}_{2} \mathrm{O}$ system which contains a mineral, Burkite having the chemical composition $\mathrm{Na}_{2} \mathrm{CO}_{3} \cdot 2 \mathrm{Na}_{2} \mathrm{SO}_{4}$. Phase/composition diagrams were found for this ternary system, based upon the absolute composition, but these concentrations were inadequate to describe the system thermodynamically since both sulfates and carbonates form acid anions. Thus, the ternary $\mathrm{Na}_{2} \mathrm{CO}_{3},-\mathrm{NaHCO}-\mathrm{H} 2 \mathrm{O}$, which has two mixed anior. minerals, Trona, $\mathrm{Na}_{2} \mathrm{CO}_{3}, \mathrm{NaHCO}_{3} \cdot \mathrm{H} 2 \mathrm{O}$ and unnamed species $3 \mathrm{NaHCO}_{3} \cdot \mathrm{Na}_{2} \mathrm{CO}_{3}$, (AKA Nacarb31) had to be evaluated and perhaps even the $\mathrm{Na}_{2} \mathrm{SO}_{4}-\mathrm{NaHSO}_{4}-\mathrm{H}_{2} \mathrm{O}$ system. To accurately predict the formation of Burkite, OLI successfully regressed several ternary systems 
obtaining ion-ion interactions and solid-liquid equilibrium constants having thermodynamic validity. This database has been provided to SRTC as a support service provided for in our licensing contract.

\section{SIMULATION OF EVAPORATION/CRYSTALLIZATION}

The new database has been used successfully now to simulate the evaporation/-crystallization experiments previously made by Karraker. Karraker started with a solution containing $0.2 \mathrm{M}$

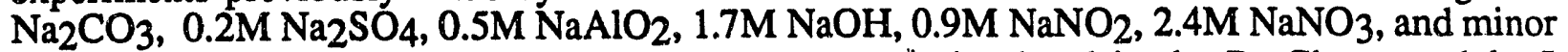
quantities of other salts. These minor salts were not simulated in the ProChem model. In Karrakers experiments, the volume was reduced by half by evaporation of water, resulting in an increase in the boiling point above $110^{\circ} \mathrm{C}$. Upon cooling, salts crystallized from solution carrying most of the sulfate in his experiments.

When the ProChem modeling of the evaporated system was run at $25^{\circ} \mathrm{C}$, the speciation predicted only the precipitation of some nitrate and carbonate; no Burkite! But when the temperature was increased to $120^{\circ} \mathrm{C}$, without allowing water to evaporate further, about $91 \%$ of the sulfate precipitated as Burkite, and the nitrate and carbonate redissolved. The simulation was recycled multiple times at $-20^{\circ}$ intervals each time removing the solids precipitated at the previous equilibrium. This simulation of fractional crystallization indicated no further crystallization until the solubility of nitrate was exceeded at about $70^{\circ} \mathrm{C}$. Since the solubility of Burkite decreases with temperature, no further precipitation of Burkite was observed at temperatures lower than $120^{\circ} \mathrm{C}$. By way of contrast the solubility of sodium nitrate increases with temperature, resulting in more precipitated nitrates cropped with each temperature drop, until at $25^{\circ}, 58.3 \%$ of the nitrate is precipitated.

Had the precipitated Burkite solids not been removed from the composition each time the temperature was reduced, then these solids would partially redissolve at each lower temperature. This mode of operation was simulated also and showed that the sulfate was precipitated to the following extent at various temperature: $120^{\circ} \mathrm{C}, 90.9 \% ; 100^{\circ} \mathrm{C}, 90.7 \% ; 80^{\circ} \mathrm{C}, 90.3 \% ; 60^{\circ} \mathrm{C}$, $88.2 \% ; 40^{\circ} \mathrm{C}, 86.1 \%$; and at $25^{\circ} \mathrm{C}, 0 \%$. The redissolution of Burkite at temperatures below $30^{\circ} \mathrm{C}$ so increases the carbonate concentration that $\mathrm{Na}_{2} \mathrm{CO}_{3} \cdot \mathrm{H}_{2} \mathrm{O}$ precipitates at $25^{\circ} \mathrm{C}$, precipitating about $22 \%$ of the carbonate but now the sulfate is entirely soluble. The high alkalinity of these waste salt compositions does not permit significant bicarbonate concentrations, thus the minerals, Trona or Nacarb31 have no chance of precipitating.

\section{PREDICTIONS ON WASTE TANK SALT CAKES}

The scavenging of sulfate into salt cake from hot evaporator bottoms undoubtedly takes place, but since this mineral is thermodynamically unstable toward hydrated forms of simple sulfates and carbonates, near existing salt cake temperatures, it should be no surprise to find evidence for it one place but not another. The dissolution kinetics of this mineral should be studied by comparison to the hydrated sodium salts to which it would convert with time and adequately low temperatures. This simulation of the solubilities of the major salt components, emulates the known properties of the waste system. However, if other mineral species are identified in the wastes, further enhancements of the database will be necessary to emulate reality as presently known. 

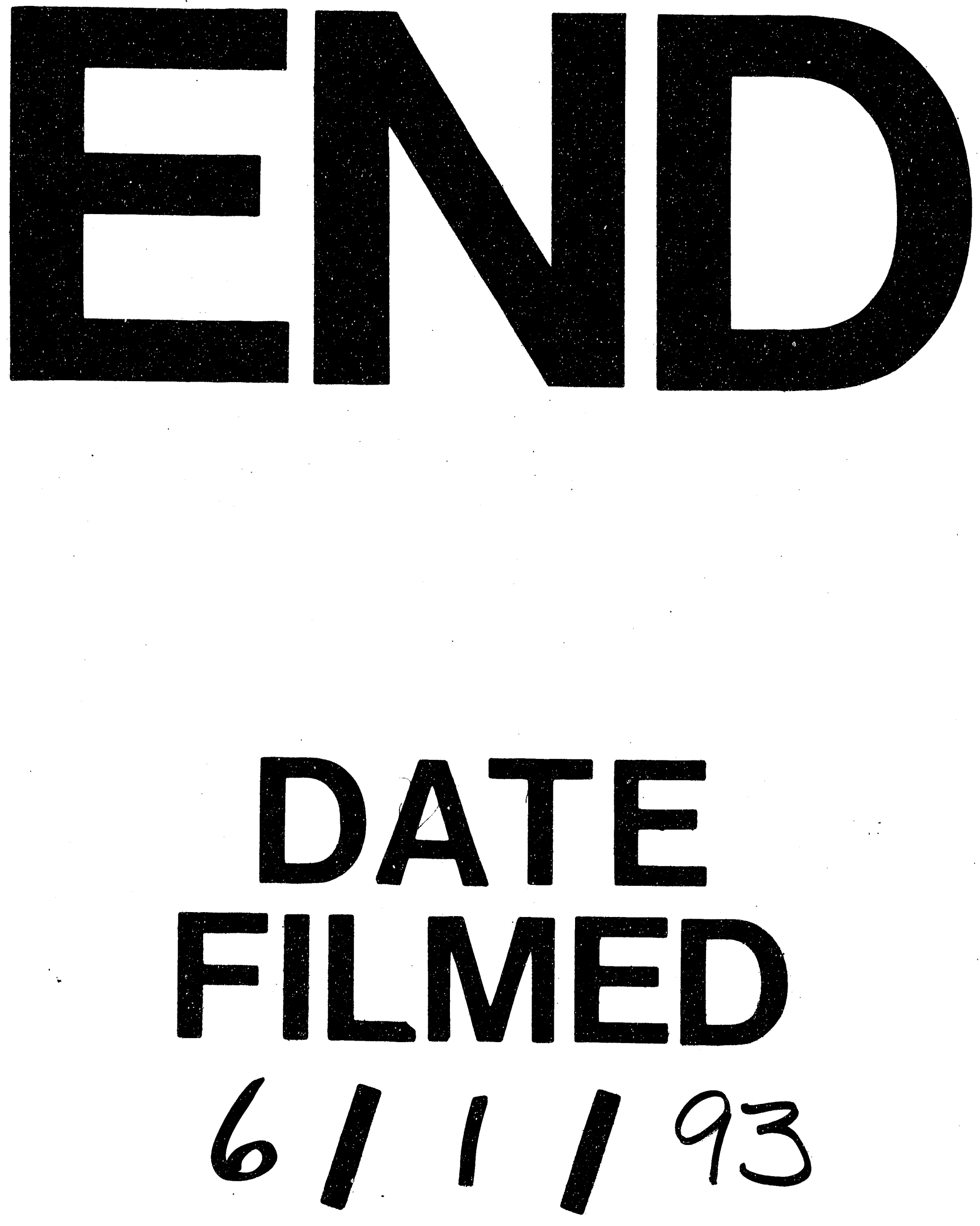
